\title{
Determinants of voluntary audit and voluntary full accounts in micro- and non-micro small companies in the UK
}

\author{
JILL COLLIS* \\ Brunel Business School, Brunel University, Kingston Lane, Uxbridge, Middlesex UB8 3PH, \\ $U K$
}

This study investigates the link between the auditing and filing choices made by a sample of 592 small private companies, which includes 419 micro-companies. It examines decisions made in connection with the 2006 accounts following the UK's adoption of the maximum EU size thresholds in 2004, and the impact of the proposed Directive on the annual accounts of micro-companies (EC 2011). The research extends the model of cost, management and agency factors associated with voluntary audit (Collis et al. 2004), and develops a complementary model for voluntary full accounts. The results show the benefits of placing full audited accounts on the public record outweigh the costs for a significant proportion of companies. In non-micro small companies, voluntary audit is determined by cost and agency factors, whereas in micro-companies it is driven by cost, management and agency factors. In both groups, the predictors of voluntary full accounts include management and agency factors, and choosing voluntary audit is one of the key factors. The study provides models that can be tested in other jurisdictions to provide evidence of the needs of micro-companies, and the discussion of the methodological challenges for small company researchers in the UK makes further contribution to the literature.

Key words: Financial reporting; micro-companies; small companies, voluntary audit; voluntary full accounts

\begin{abstract}
Acknowledgements
I am grateful to Mike Page, the editor and the anonymous reviewers for their detailed comments and advice. I would also like to thank Robin Jarvis, Len Skerratt and Hannu Ojala for their support, and acknowledge the helpful feedback received from delegates at the BAFA, EAA and EUFIN conferences on previous versions of the paper.
\end{abstract}

*Email: jill.colis@brunel.ac.uk 


\section{Introduction}

This study focuses on a sample of 592 small companies in the UK, which includes 419 companies that are likely to be categorized as micro-companies under the European Commission's proposed Directive on accounting for 'micro-entities' (EC 2007, 2011). The sample represents a subset of private companies that took part in a survey commissioned by the Department for Business, Enterprise and Regulatory Reform (BERR) ${ }^{1}$ (Collis 2008). The purpose of this study is to contribute to the literature by investigating the determinants of two voluntary behaviours in micro and non-micro small private companies: non-statutory audit and the filing of voluntary full accounts. The research examines the reasons for the auditing and filing decisions made in connection with the companies' financial statements for accounting periods ending in 2006 in the context of the UK raising the size thresholds for a small company to the EU maxima in 2004. It also explores the potential impact of the proposed Directive on accounting for 'micro-entities', which is intended to reduce accounting and financial reporting obligations for approximately 5.3 million companies, representing some $75 \%$ of entities within scope of the Fourth Company Law Directive (EC 2008a). It has the potential to affect some $60 \%$ of registered companies in the UK (BIS/FRC 2011).

The Fourth Directive requires limited liability entities to prepare and register annual accounts, which must be audited by one or more persons entitled to carry out such audits. The rationale for the requirement to make the accounts available at a registry is that anyone dealing with a limited liability company should be able to see the financial statements. Member States are permitted to provide options for qualifying small or medium-sized entities to register less detailed abbreviated accounts ${ }^{2}$ in place of the full statutory accounts, and for qualifying small entities to forgo the statutory audit. These concessions stem from recognition of the increasingly important role played in the economy by small and mediumsized entities, which have been dubbed the backbone of Europe's economy (EC 2008b). For example, UK statistics relating to the start of 2010 show that $97 \%$ of the 1.2 million active companies $^{3}$ (including subsidiaries) were small (0-49 employees) and accounted for $31 \%$ of jobs and $29 \%$ of turnover in the private sector (BIS 2011, Table 3).

The Fourth Directive specifies the maximum thresholds that Member States can set for small entities to qualify for audit exemption and abbreviated accounts. ${ }^{4}$ Entities must meet at least two of the three size tests shown in Table 1 relating to the maximum level of turnover, total 
assets and average number of employees for the financial year. The table also shows the proposed thresholds for the new category of micro-entity. ${ }^{5}$

\section{[Insert Table 1 hereabouts]}

Depending on the choices made by the Member State, the draft Directive on the annual accounts of micro-entities proposes that a company that qualifies as a micro-entity will be exempt from the requirement to keep accounts on prepayments and deferred income for certain headings, thus limiting accounting information to key elements and permitting a minimum level of transparency. Member States will also be able to discharge micro-entities from the obligation to provide notes to the accounts (in which case the information will appear in the balance sheet) and calculate overheads at the year end. In addition, Member States will be able to exempt micro-entities from the obligation to publish annual accounts, provided the balance sheet information is registered by a competent authority, transmitted to the trade register and available on request.

These regulatory relaxations for micro-entities stem from a 'think small first' approach, which rests on the assumption that the requirements are a burden to very small entities, the reduction of which would boost Europe's economy (EC 2007). However, there is a paucity of up-to-date research on the benefits that might be lost. Moreover, previous studies focus on the auditing or filing options separately, whereas in the financial reporting cycle the auditing and filing choices coincide at the year end. A further limitation is that previous impact assessment studies on raising the thresholds in the UK have necessarily focused on predicted behaviour rather than the actual choices made. The present research addresses these gaps.

The remainder of the paper is organised as follows: Section 2 outlines the development of differential reporting in the UK; Section 3 reviews the literature and develops the hypotheses, while section 4 describes the methodology. The results are presented and discussed in section 5 and the final section draws conclusions on the contribution and limitations of the study.

\section{Development of differential reporting in the UK}

Statutory corporate reporting stems from the publicity doctrine, which asserts that the publication of the annual report and accounts and other information is part of the price 
companies must pay for their limited liability status (Holgate 1995). The Companies Act 2006 incorporates EU Directives and sets the general regulatory framework, which includes the requirement that directors register the entity's annual report and accounts, and distribute them to members. The development of company law is the responsibility of the Department for Business, Innovation and Skills (BIS) and the official Registrar of Companies operates under the name of 'Companies House'. Companies House is an executive agency of BIS and has responsibility for incorporating and dissolving limited companies, examining and storing company information delivered under the Companies Act and related legislation, and making that information available to the public (Companies House n.d.).

The principle of differential financial reporting on the basis of size was introduced in UK company law when the option for small and medium-sized entities to file less detailed accounts, known as abbreviated accounts, was provided in the Companies Act $1981 .^{6}$ In the case of small entities, this option gives relief from the requirement to file an income statement and a directors' report, and merely requires the publication of an abbreviated balance sheet and related notes. ${ }^{7}$ However, full accounts must be distributed to shareholders. Although drawn from the full accounts, abbreviated accounts 'do not purport to give a true and fair view and on commercial/confidentiality grounds they exclude financial information that is integral to the true and fair view' (PwC 1999, p. 36005). In 1994 the Companies Act 1985 was amended to permit qualifying small entities to claim exemption from the statutory audit.

When the concessions were first introduced in the $\mathrm{UK},{ }^{8}$ the size tests were set lower than the EU maxima and the turnover threshold was set at a lower level for audit exemption than for the abbreviated accounts option. Subsequently, the thresholds were raised in steps and by 2004 they had been standardised for all accounting and auditing options and harmonised with the EU maxima. In April 2008, the UK thresholds were raised once more to align them with the revised EU maxima. The UK was not alone in adopting the EU maxima and research suggests that $47 \%$ of Member States had fully implemented the filing options in the Fourth Directive by 2003 (EC 2005). ${ }^{9}$

Unless it is excluded for reasons of public interest, ${ }^{10}$ a company in the UK will generally qualify as small if it meets two or more of three size criteria, shown in Table 1, in its first 
year. ${ }^{11}$ In a subsequent financial year, the entity must qualify as small or satisfy the size tests in that year and the preceding year. The conditions for exemption from audit are that the entity qualifies as small in relation to that year and meets both the turnover and balance sheet criteria for that year. ${ }^{12}$ However, if audit is required by shareholders holding at least $10 \%$ of issued share capital, the company cannot forgo the statutory audit.

Companies House statistics provide a breakdown of the proportion of active companies filing audit exempt accounts, full accounts and abbreviated accounts. However, the statistics do not distinguish between statutory and voluntary audit or between statutory and voluntary full accounts; nor do they indicate whether the full accounts from which the abbreviated accounts were derived were audited. More importantly, the percentages relate to the proportion of companies on the register, rather than the proportion of companies that qualify for a particular concession. For example subsidiaries of large groups do not qualify for exemption, but are apparently treated as 'small' in the statistics. A further problem is that official statistics are difficult to compare over time due to the adoption of different size thresholds for different elements of the financial reporting regime prior to 2004 and increases made for indexation purposes.

The full accounts from which the abbreviated accounts are drawn may be audit exempt and unaudited, or they may have been audited on a voluntary basis. Under the Companies Act 2006 c.46, s.449), the directors must file a special auditor's report if the company files abbreviated accounts and is not exempt from audit or chooses voluntary audit. The special auditor's report must include a statement that in the auditor's opinion the entity is entitled to deliver abbreviated accounts and that the abbreviated accounts have been properly prepared in accordance with regulations. The auditor's report on the company's annual accounts need not be delivered. However, where the auditor's report on the full accounts is qualified, directors filing abbreviated accounts must include a copy of the special auditor's report setting out the qualification. Where the auditor's report on the full accounts is unqualified but contains an emphasis of matter paragraph, that paragraph must be included in the special report, together with any further materials needed to understand it. These requirements demonstrate the link between audit and the filing decision.

In 1999 the Company Law Review Steering Group completed a long-term review of core company law (DTI 1999). Given the economic importance of small and closely-held 
businesses in the UK and further afield in Europe, the Steering Group concluded that modern company law should follow 'think small first' principles. To improve the usefulness of the accounts, the Group recommended that small and medium-sized entities (SMEs) 'should no longer be able to file uninformative "abbreviated" accounts' (DTI 2001, p. 3), arguing 'it is important that company accounts should be generally available' (DTI 2002, p. 2), which reflects the publicity doctrine mentioned earlier. The outcome of the review was the Companies Act 2006, which introduced new provisions but also partly rewrote the Companies Acts 1985 and 1989 with a view to making the provisions for SMEs simpler and easier to understand. However, the abbreviated accounts option was retained.

\section{Literature and development of hypotheses}

\subsection{Introduction}

A qualifying small company that chooses to register audited full accounts is making voluntary disclosures. As in the large company literature, these voluntary disclosures can be defined as 'disclosures in excess of requirements [that] represent free choices on the part of company managements to provide accounting and other information deemed relevant to the decision needs of users of their annual reports' (Meek et al. 1995, p. 555). Over recent decades considerable attention has been paid to developing theory in the context of voluntary disclosures by large, listed companies (for example, Firth 1979, Leftwich et al. 1981, Meek et al. 1995, Schleicher 1998, Holland 2005), but very little research has been carried out in small, private companies. However, caution must be exercised in adopting a theoretical framework or research methods ${ }^{13}$ based on a large company template. The motivations of the directors of large, listed companies operating in the capital markets are highly likely to differ from motivations of the owner-directors of small private companies (see section 3.3).

In the small company literature, comparison of previous UK studies is problematic due to changes in accounting regulation, increases in the size thresholds and fluctuations in currency values. Moreover, some of the previous studies are now somewhat dated or too small to permit generalisation, although they provide valuable insights (for example, Page 1984, Keasey and Short 1990, Freedman and Goodwin 1993, Pratten 1998, Tauringana and Clarke 2000, John and Healeas, 2000, Lin-Seouw 2001, ICAS 2002, Marriott et al. 2006). The usefulness of studies conducted in other jurisdictions is limited by the need to take account of 
country-specific factors such as social, economic and cultural differences, notions about the objective of financial reporting, and the relative importance of principles and rules (Haller and Walton 2003).

A questionnaire survey by Collis and Jarvis (2000) for the Institute of Chartered Accountants in England and Wales (ICAEW) examined the views of the directors of 385 companies filing full accounts with a turnover up to $£ 4.2$ million (the proposed EU maximum for a small company at the time of the study) and found that $63 \%$ predicted they would opt for audit if offered exemption. ${ }^{14}$ Further analysis of that data by Collis et al. (2004) identified a number of cost, management and agency factors that influenced demand for voluntary audit. These factors were tested again in a survey by Collis (2003) for the Department of Trade and Industry (DTI), which examined the views of the directors of 790 small companies with a turnover up to $£ 4.8$ million (the proposed EU maximum for a small company at that time). This found that $42 \%$ of respondents predicted they would have a voluntary audit. ${ }^{15}$

In the context of the debate over raising the thresholds for audit exemption in the UK, Collis (2010) examined the sufficiency of turnover as a surrogate for demand for voluntary audit using the 2003 UK data and comparing it with data from Denmark. She found evidence in both countries that turnover alone is not a sufficient surrogate for the cost and benefits of audit, which are broadly similar in both countries. The model developed by Collis et al. (2004) was also tested with data from Finnish companies with fewer than 10 employees by Niemi et al. (2012). This provides evidence of the robustness of the model in a third regulatory setting. These studies suggest that despite regulatory differences (in particular, definitions of size), many of the drivers of demand for voluntary audit are common to the UK, Denmark and Finland. Although these studies contribute to the theoretical framework for this study, their findings suffer from the limitation that they are based on the directors' predicted decisions and focus on decisions by companies registering full accounts.

Little is known about the factors that determine the filing choice in SMEs. The Professional Oversight Board for Accountancy ${ }^{16}$ (POBA) reported that research it commissioned to examine 355 sets of accounts at Companies House in 2006 found approximately 60\% were abbreviated, which was comparable with the findings of its questionnaire survey of 600 small and medium-sized companies, where just over $50 \%$ reported they had filed abbreviated 
accounts (POBA 2006, p. 24). This suggests a significant proportion of companies register voluntary full accounts. However, there is little evidence of the directors' reasons for their filing choice and no study has investigated any link between voluntary disclosure and voluntary audit. The present study investigates the following research questions:

1. What factors influence the decision to opt for voluntary audit in small companies?

2. What factors influence the decision to register voluntary full accounts in small companies?

The following review of the literature examines the costs and benefits of voluntary audit and voluntary full accounts for small companies and develops the associated hypotheses.

\subsection{Cost}

In a broad sense the costs of audit and disclosure can be conceived as 'cash costs', such as auditors' fees, employees' salaries and filing fees, and 'proprietary costs', such as losses incurred from the use of information by competitors. There is likely to be a substantial fixed element in the cash costs of audit and disclosure so that the relative cash cost declines as turnover increases. Collis (2003) found that the modal saving from discontinuing audit for small companies with a turnover up to $£ 1$ million (the UK exemption threshold at the time of the study) was $£ 1,000$, which is a significant saving. Collis et al. (2004) found that small companies with a larger turnover were more likely to choose voluntary audit. Total assets and number of employees were also tested, but were not found to add significant information. The authors concluded that these two size tests could be excluded as criteria for audit exemption. However, the study also demonstrated that size alone does not capture all the costs and benefits of audit in small companies.

In 1995 the estimated additional cost of preparing abbreviated accounts was $£ 100-£ 250$ (DTI 1995, p. 12) and the DTI gave this as the main reason why more companies had not taken up the option. This view was shared by the ICAEW (1995, p. 4): 'We believe that many small companies do not bother to convert the accounts they have to send to shareholders into abbreviated accounts because there is an attendant expense'. Subsequent case study evidence (Marriott et al. 2006) suggested a typical fee of around $£ 100$, but it was found that some accountants made no charge because of the ease with which accountancy software allowed 
them to generate abbreviated accounts from the full accounts prepared for shareholders. Given the widespread use of accountancy software, this suggests the cost of the filing decision may now be small.

The focus on relieving the disproportionate burden placed on small companies and the decision to raise the UK size thresholds to the EU maxima in 2004 suggest that turnover captures the cost of audit, but some studies have used it as a surrogate for separation of ownership and control (Chow 1982, Tauringana and Clarke 2000) or to measure the value of wealth at risk if the financial statements were not audited (Abdel-Khalik 1993). In this study, relative cash cost is assessed in two ways. The first is that turnover is used as a proxy for inverse relative cash cost. As explained above, because of the economies of scale, turnover is inversely related to the relative cash cost of audit. The second is that respondents were asked directly about the extent of the 'cost burden' of their audit and filing decisions.

This literature leads to the following cost hypotheses:

H1 Voluntary audit is positively associated with turnover.

$\mathrm{H} 2$ Voluntary audit is negatively associated with the perceived cost burden.

H3 Voluntary full accounts are positively associated with turnover.

H4 Voluntary full accounts are positively associated with the perceived cost burden (due to the additional cost of producing abbreviated accounts).

\subsection{Management factors}

In 1995, some 14 years after the abbreviated accounts option was introduced in the UK, there was some concern that the estimated take-up was only 35\% of eligible companies (DTI 1995, p. 12). However, 10 years later it had risen to an estimated 43\% (DTI 2005, p. 31). The basis of these estimates is not known, given the absence of a sampling frame of eligible companies. The evidence provided by POBA $(2006$, p. 24) that suggests some $50 \%$ of small and medium-sized companies filed abbreviated accounts in 2006 does not tell us what proportion of the other $50 \%$ had volunteered full accounts or were under a statutory obligation to file full accounts. 
Research in the 1980s (Page 1981, 1984) contended that the directors of small companies had little knowledge of accounting. Over the years this may have changed, since Collis and Jarvis (2000) found that the principal directors of $67 \%$ of small companies in their sample had trained in, or studied, business or management subjects. Nevertheless, if an entity is close to the size thresholds, the question of whether it qualifies for the small company options must be reviewed regularly and this may lead to the directors seeking professional guidance.

Accountants are the main source of advice to small firms in the UK (Bennett and Robson 1999 and 2003, Gooderham 2004, POBA 2006, Dyer and Ross 2007) and play a key role in advising on regulation (Blackburn et al. 2006). Traditionally, the financial reporting function is outsourced and the majority of smaller companies rely on an external accountant to prepare the statutory accounts (Page 1981, Carsberg et al. 1985, Collis and Jarvis 2000, Collis 2003, 2008). Directors faced with the choice for the first time are likely to benefit from the accountant's experiences with similar companies and an accountant retained for some years is likely to have considerable knowledge of the business and the directors' future plans, and be in a strong position to discuss the costs and benefits of the filing options. Under the model of economic rationality proposed by Weber (1968), a cost and benefit analysis represents formal rationality. Recent evidence (Kitching et al. 2011) shows that considerable importance is attached to the accountant's analysis of the costs and benefits: $64 \%$ of accountants with small company clients advised them to file abbreviated accounts if they (the accountants) considered it appropriate, compared with $26 \%$ of accountants who informed clients of the advantages and disadvantages and let the directors decide. The research found that accountants who advised clients to file abbreviated accounts were more likely to report that all their clients filed abbreviated accounts, and this suggests that the accountant's advice is generally followed. The fact that some accountants discuss the advantages and disadvantages with the directors of small companies suggests that a periodic review of the costs and benefits takes place.

The above discussion leads to the following management hypotheses:

H5 Voluntary audit is positively associated with taking the accountant's advice.

H6 Voluntary audit is positively associated with reviewing the costs and benefits.

H7 Voluntary full accounts are positively associated with taking the accountant's advice. 
H8 Voluntary full accounts are positively associated with reviewing the costs and benefits.

Collis et al. (2004) found that voluntary audit is associated with companies whose directors believed that audit improves the quality of the financial information and provides a check on internal books and records. Most small companies are closely held family-owned businesses (Bolton 1971, Poutziouris et al. 1998, Collis and Jarvis 2000, Collis 2003, 2008). Therefore, opportunistic behaviour by management, at the expense of shareholders, may be less of a problem than it is in larger companies where there is separation of ownership and control. Collis et al. (2004) identified the management benefits from an independent audit as the check on internal controls and the improvement in the quality of the financial information, which reduces information risk. In small companies, inherent risk and internal control risk are high (Collis et al. 2004). Consequently, there is a strong likelihood of material misstatements arising in the financial statements and a strong likelihood that such misstatements will not be detected in a timely fashion by internal controls. Agency theory (Jensen and Meckling 1976) suggests a reduction in control risk and inherent risk would lower agency costs (Hossain et al. 1995, Watson et al. 2002, Prencipe 2004) and lead to an economically rational decision (Collis 2010). This discussion leads to the following management hypotheses:

H9 Voluntary audit is positively associated with agreement that it acts as a check on the accounting systems and records.

H10 Voluntary audit is positively associated with agreement that it improves the quality of financial information.

Interviews with small companies, soon after the abbreviated accounts option was introduced in the UK, found that in general directors 'did not see the disclosure of commercial information (for example, turnover and stock [inventory]) about a company as a burden, in that it gave significant help to competitors' (Carsberg et al. 1985, p. 6). Ten years later, the directors still did not see 'a significant disadvantage in making publicly available more information than they strictly need' (ICAEW 1995, p. 4). However, abbreviated accounts may offer benefits if there is 'a competitive or other advantage to be gained by not disclosing particular information' (DTI 1995, p. 12). A study of medium-sized companies in the manufacturing sector found companies with intrinsic advantages (the ability to earn long- 
term above average profits through features of the business) are less likely to file abbreviated accounts. In that study, age was used as a proxy 'since companies survive longer when they have greater intrinsic advantages' (Dedman and Lennox 2009, p. 224). Unless it occupied a niche market, this could also apply to a small company trying to protect its position in the industry by withholding information from rivals. The following management hypotheses test these propositions:

H11 Voluntary full accounts are negatively associated with the perceived disclosure burden.

H12 Voluntary full accounts are negatively associated with the age of the company.

A survey of credit analysts and credit managers (Morris and Omrod 1990) found that when full accounts were filed by small companies, they were the most important source of information for assessing credit risk. When abbreviated accounts were filed, approximately half the information omitted could be found from alternative sources, but the cost of doing so was high. Interview data from banks, commercial credit reference agencies and credit insurance companies (Kitching et al. 2011) confirms that abbreviated accounts offer limited insights into the financial performance and position of a company, and that other information is needed to assess credit risk. It is likely that the directors of small companies are aware of this because some file voluntary full accounts that have been audited on a non-mandatory basis to improve their credit rating (Collis 2003, Marriott et al. 2006). ${ }^{17}$ These propositions are tested by the following management hypotheses:

H13 Voluntary audit is positively associated with agreement that it has a positive effect on the credit rating score.

H14 Voluntary full accounts are positively associated with voluntary audit.

\subsection{Agency factors}

Collis (2003) used turnover as a proxy for the inverse relative cash cost of audit and to capture whether the company is large enough to have external shareholders and/or external lenders. She argues that these factors are better explained by the theory that the directors will be willing to bear the cost of audit due to the beneficial role the audited accounts play in supporting agency relationships (Jensen and Meckling 1976) with principals who are distant 
from the actions of management. Power (1997) contends that, in small companies, principals include external shareholders, lenders and creditors who cannot verify the information. Since such agency relationships are unlikely to be transient, it is probable that, when thresholds are raised, companies with agency relationships will continue to file full audited accounts on a voluntary basis to mitigate the problem of information asymmetry. This will represent consistency in terms of financial reporting policies rather than force of habit.

Existing and potential investors are considered to be one of the main groups of users of the published accounts (ASB 1999, IFRS 2010). Investors in large companies are external shareholders who delegate authority for managing the business to the directors, which leads to information asymmetry. However, investors in many small private companies are ownerdirectors (Page 1984, Carsberg et al. 1985, Collis 2003, 2008). Nevertheless, 'even in the very smallest company disputes can arise between shareholders and the audited accounts can be an essential protection' (Freedman and Goodwin 1993, p. 128). Moreover, information asymmetry can be present among owner-directors if they lack the skills necessary to interpret the financial information (Power 1997). These views are supported by evidence of demand for audit in small companies that are not wholly family-owned (Collis 2003, Collis et al. 2004) and in small companies that have one or more shareholder who is not involved in the day-to-day management of the business (Collis 2003). The study of very small companies in Finland (Niemi et al. 2012) found that outsourcing critical accounting functions creates a need to control for information asymmetry between the company and the external accountant, which increases the likelihood of independent audit. On the other hand, if the external accountant provides tax advice, demand for voluntary audit is likely to decrease.

Banks are the main source of external finance for small firms (Cosh and Hughes 2003) and recent research (Cosh et al. 2009) shows that overdrafts and credit cards are the most commonly used forms of finance. The audited accounts play an important role in the lending decision (Berry et al. 1987, Berry and Waring 1995, Berry et al. 1993, Deakins and Hussain 1994, ACCA 1998). However, lenders have the economic power to demand special purpose financial statements and banks can monitor cash flows in order to assess lending risk. Berry et al. (1987) suggest that bankers consider that the full statutory financial statements to be the most important source of documentary information because they are more reliable than the management accounts, but information about the person, the business and the lending 
proposition are also key factors (Berry et al. 2003). A global survey of 559 bankers (IFAC/The Banker 2009) shows that lenders increasingly look at cash flow information, collateral and customer history in addition to the financial statements, key risk indicators and industry trends. Other evidence (Collis 2003, 2010, Collis et al. 2004, Collis and Jarvis 2002) indicates that small companies file voluntary audited full accounts to maintain relationships with the bank and to send positive signals to lenders, suppliers and customers that the business is well managed (Marriott et al. 2006). A UK study of 5,139 small companies filing full accounts (Lennox and Pittman 2011) provides evidence that low-risk companies attract upgrades to their credit rating when they signal their favourable borrowing characteristics by choosing voluntary audit.

Prior research suggests that small companies tend to follow lifestyle or satisficing strategies because survival and stability are often more important than growth and profit-maximisation. The latter (growth and profit-maximisation) are the main strategies pursued by large companies (Jarvis et al. 1996). Nevertheless, a survey of SMEs during the current economic crisis (Cosh et al. 2009) shows that 59\% intended to grow over the next three years. According to Olsson (1980), filing full audited accounts would be advisable if the shareholders were intending to sell the business, plan a flotation or seek another form of external investment, although Collis (2003) found only $1 \%$ of small companies were planning a listing in the foreseeable future.

This literature leads to the following agency hypotheses:

H15 Voluntary audit is negatively associated with the company being wholly family owned.

H16 Voluntary audit is positively associated with the company having shareholders who are not involved in the day-to-day management.

H17 Voluntary audit is positively associated with perceived demand from existing investors.

H18 Voluntary audit is positively associated with perceived demand from lenders.

H19 Voluntary audit is positively associated with perceived demand from suppliers or customers.

H20 Voluntary full accounts are positively associated with perceived usefulness to users. 
H21 Voluntary full accounts are positively associated with perceived use by potential investors.

H22 Voluntary full accounts are positively associated with perceived use by lenders.

H23 Voluntary full accounts are positively associated with perceived use by suppliers or customers.

H24 Voluntary full accounts are positively associated with perceived use by credit rating agencies.

\section{Methodology}

\subsection{Sample selection and data collection}

This study focuses on 592 small private companies. These represent a subset of 1,294 small and medium-sized companies that responded to a postal questionnaire survey in September 2007, which had been commissioned by BERR as part of a regulatory impact assessment (Collis 2008). The questions were guided by case study research (Marriott et al. 2006) and the draft proposals for regulatory reform in the EU (EC 2007). The questionnaire was developed jointly with BERR, discussed with experts in the accountancy profession and piloted with a convenience sample of directors of six small private companies. It was then sent to 9,458 private companies in the UK which had been selected from the Fame database ${ }^{18}$ if they had filed their accounts for 2006 by 31 August 2007 and met the following size criteria: ${ }^{19}$

- $\quad$ total assets not exceeding $£ 12.9$ million

- an average of no more than 250 employees during the financial year.

Companies with activities in all sectors were included, apart from Section $\mathrm{J}$ Financial Intermediation (SIC 66, 67 and 68). ${ }^{20}$ Only independent companies were included, since subsidiaries may be part of larger, non-exempt groups. Table 2 summarises the selection criteria and search results.

[Insert Table 2 hereabouts] 
The sample comprises small companies on Fame that were not in the financial intermediation sector, and had a year-end before 31 October 2006 or had filed early. ${ }^{21}$ As a non-financial measure of size, number of employees offers the advantage of being more stable than turnover (the latter being more vulnerable to economic conditions and inflation), but the number of employees is only disclosed in the notes if the company files full accounts. It is not known how Fame gathered or estimated the number of employees for those filing abbreviated accounts. If the disclosure was voluntary, there may be bias towards companies that are inclined to adopt other types of voluntary behaviour.

Responses need to be evaluated in the light of such biases, many of which result from the lack of a complete and up-to-date sampling frame, and conflicting data about the number of small independent companies. ${ }^{22}$ Fame contains information drawn from the annual reports and accounts registered at Companies House in the UK and the Companies Registration Office in Ireland. According to the publisher (Bureau van Dijk 2011), Fame aids financial analysis by presenting the accounts in a standard format and contains information on 7 million companies in the UK and Ireland, which include:

- 2 million companies in a detailed format

- a further 200,000 companies in a summary format

- details of 700,000 companies that are active but are not required to file accounts, or which have yet to file their accounts

- 4 million companies that are no longer active, but which are included to aid research into patterns in default and to confirm previous existence. ${ }^{23}$

Table 2 shows that at 31 August 2007 when the companies were selected, Fame claimed to contain 2.6 million active companies. Fame's publisher points out that it does not include all companies with a turnover under $£ 0.5$ million, but does not provide a rationale for this underrepresentation. There are several potential explanations. For example, in 2007 private companies could register their accounts up to 10 months after the end of their accounting reference period, ${ }^{24}$ but some new companies may not have survived long enough to file accounts. The poor representation of very small companies in this study is a limitation that is difficult to remedy, but which nevertheless must be borne in mind when interpreting the results. 
Comparing the population of companies on Fame with the data provided by Companies House (2007) and the SME statistics published by BERR (2007) is problematic due to differences in the periods covered, the regions and sectors included, and the type of analysis provided.

According to Companies House (2007, Table A2), the total number of public and private companies incorporated in Great Britain and on the register at 31 March 2007 was 2.34 million. Two reasons for the difference between this figure and the 2.62 million on Fame are that Companies House excludes companies registered in Northern Ireland and the Republic of Ireland, and Fame does not include all companies with a turnover under $£ 0.5$ million. Companies House (2007, Table F2) shows the number of annual accounts that had been registered at 31 March 2007 was only 1.65 million. The difference between the number of companies and the number of accounts registered is likely to be due to new registrations ${ }^{25}$ and some companies being dissolved, in liquidation or in the course of being removed from the register. ${ }^{26}$ Although Table F2 analyses the accounts filed by type, there is no breakdown by size of company. ${ }^{27}$

The SME statistics published by BERR (2007, Table 3) differ from the Companies House statistics because the former include companies registered in Northern Ireland but exclude those in the Republic of Ireland. This source shows the total number of companies in the UK at the start of 2007 was 1.2 million. One reason for the BERR statistics being lower than the Companies House data is that definition of private sector used by BERR (2007) excludes the non-profit sector. Another reason is almost certainly due to the exclusions of entities that are not registered for Value Added Tax or Pay As You Earn. There are many companies that fall into this category, including subsidiaries, and it is not clear how subsidiaries are dealt with in the SME statistics. Although BERR (2007) does not provide an analysis of the type of accounts filed, Table 3 of the SME statistics gives a breakdown by turnover ${ }^{28}$ and number of employees. Since Companies House does not collect turnover or employee data from all small companies, it is likely that this analysis is based on estimates from VAT returns, PAYE information and other sources. POBA (2006, p. 7) reported that at least $95 \%$ of the $1.1 \mathrm{~m}$ active companies that filed accounts in 2004-5 were small and it is likely that this was 
estimated from SME statistics at the start of 2005 (SBS 2006, Table 2), where further analysis indicates that $95 \%$ were small in terms of number of employees (0-49).

Another challenge for the small business researcher is the relatively low response rate to surveys since the directors may be sceptical about the relevance of academic research or simply too busy running the business to participate (Curran and Blackburn 2001). The response rate to Collis (2008) was $14 \%$ without reminders, which was lower than $17 \%$ achieved by Collis and Jarvis (2000) and 30\% achieved by Collis (2003), both of which used reminders. Other differences were that the Collis (2008) survey covered a wider range of issues, the BERR logo was unknown and there were three postal strikes during the survey period. Nevertheless, the response rate of $14 \%$ was higher than other UK studies; for example, $12 \%$ by Poutziouris et al. (1998), $11 \%$ by the ICAEW (1996) and $13 \%$ by the Bolton Committee's accounting survey in $1971 .^{29}$ Response rates to recent accounting surveys of small companies in continental Europe have also been low; for example, $10 \%$ in Germany (Mages 2008, Eierle and Haller 2009) and only 6\% in Belgium (Coppens and Van Wymeersch 2007).

\subsection{Companies in the analysis}

As stated, the companies analysed are a subset of 1,294 small and medium-sized private companies responding to a questionnaire survey conducted for BERR (Collis 2008). In response to a question that asked whether the company's 2006 accounts had been audited, 702 companies stated that they had been audited because the company was above the size thresholds and the remaining 592 companies stated that their accounts had been audited on a voluntary basis or that they were not audited because the company was exempt. From this it was deduced that these 592 companies qualified as small in 2006. These are the small companies in the analysis. There was some size bias in this sample, which tended to be slightly smaller (in terms of total assets) than the small companies that did not respond to the questionnaire.

Univariate analysis of the survey responses from these 592 small companies found that $39 \%$ had opted for voluntary audit in 2006 and $61 \%$ had chosen exemption. ${ }^{30}$ In addition, $51 \%$ had filed voluntary full accounts in 2006 and 49\% had filed abbreviated accounts. Further analysis suggests that $419(71 \%)$ of the 592 small companies could be classified as micro- 
companies, ${ }^{31}$ of which $22 \%$ had opted for voluntary audit in 2006 while $78 \%$ had chosen exemption. In respect of filing, $45 \%$ had filed voluntary full accounts and $55 \%$ had filed abbreviated accounts.

As previously stated, all 592 small companies had filed their 2006 accounts by the end of August 2007 and, because they were surveyed in September 2007, the respondents were recalling recent events. In $91 \%$ of cases the respondent was the director or company secretary. Both these factors increase the validity of the responses. Their answers regarding their financial reporting choices corresponded with the Companies House data on Fame and were consistent with their responses to related questions. Key characteristics of the small companies were as follows:

- $67 \%$ had either one or two shareholders

- $66 \%$ were owner-managed ${ }^{32}$

- $57 \%$ were wholly family-owned (includes companies with only one owner)

- $34 \%$ had been incorporated for up to 5 years

- in $77 \%$ of cases an external accountant had prepared the 2006 accounts

- $70 \%$ were in favour of filing exemption for micro-companies.

External sources of finance comprised: banks (33\%); hire purchase and/or leasing (22\%); factoring/invoice discounting (6\%) and forward payments $(6 \%)$. Internal sources of finance used were: directors' loans (37\%); loans from family and friends (5\%); and loans from the company's pension fund (2\%).

The costs and benefits of voluntary audit and voluntary full accounts for small companies are tested in two related logistic regression models described in sections 4.3 and 4.4, which are based on the following general model:

Financial reporting choice $=f(\operatorname{cost}$, management factors, agency factors $)$

\subsection{Variables in the model of demand for voluntary audit}

Table 3 describes the variables in the analysis of demand for voluntary audit, where VOLAUDIT (the dependent variable) captures whether the 2006 accounts were audited on a 
voluntary basis (coded 1 ) or the company chose exemption (coded 0 ). The source of the data is the survey by Collis (2008).

[Insert Table 3 hereabouts]

\subsubsection{Cost}

TURNOVER $(\mathrm{H} 1)$ is a proxy for the cost of audit and captures ordinal data relating to the company's turnover in 2006, which was coded from 1 to 8 as indicated in Table 3 . It is expected to be positively associated with voluntary audit. COSTAUDIT (H2) captures ordinal data from the survey and measures the extent of agreement (see Table 3 ) that the cost of audit was a major burden. It is expected to have a negative association with voluntary audit. This study uses a survey response to measure the directors' perceptions of the cost burden, whereas Collis (2003) and Collis et al. (2004) drew the same conclusion based solely on turnover as a proxy for cost.

\subsubsection{Management factors}

$A D V I C E(\mathrm{H} 5)$ is a dummy variable $(1,0)$ that captures whether the company received advice on accounting or auditing regulations from an external accountant in 2006. It is expected to have a positive association with voluntary audit. REVIEWAUDIT (H6) is an ordinal variable that captures the extent of agreement (see Table 3) that the costs and benefits of audit had been reviewed since 2003. It is expected to have a positive association with voluntary audit. CHECK (H9) QUALITY (H10) and CREDITSCORE (H13) are ordinal variables that capture the extent of agreement (see Table 3 ) that audit acts as a check on the accounting systems and records, improves the quality of the financial information and has a positive effect on the credit rating score respectively. These variables are expected to be positively associated with voluntary audit.

\subsubsection{Agency factors}

FAMILY (H15) is a dummy variable $(1,0)$ that captures whether the company is wholly family owned and is expected to have a negative association with voluntary audit. EXOWNERS (H16) is a dummy variable $(1,0)$ that captures whether the company has external investors without access to day-to-day financial information and is expected to be positively associated with voluntary audit. INVESTORSAUDIT (H17), LENDERSAUDIT (H18) and SUPPSCUSTSAUDIT (H19) capture ordinal data measuring the extent of agreement (see 
Table 3) that shareholders, banks/lenders, and major suppliers or major customers require audited accounts respectively. These variables are expected to have a positive association with voluntary audit.

\subsubsection{Control variable}

CONSISTENTAUDIT is an ordinal variable that measures the extent of agreement (see Table 3) that consistency with the audit decision in previous years was a major factor and controls for the effect of tradition or habit.

[Insert Table 3 hereabouts]

\subsection{Variables in the model of demand for voluntary full accounts}

Table 4 describes the variables in the analysis of the demand for voluntary full accounts, where VOLFULL (the dependent variable) and captures whether the company filed voluntary full accounts for 2006 (coded 1) or abbreviated accounts (coded 0). Unless stated otherwise, the source of the data is the survey by Collis (2008).

[Insert Table 4 hereabouts]

\subsubsection{Cost}

TURNOVER $(\mathrm{H} 3)$ is a proxy for the cost of the filing choice and captures ordinal data relating to the company's turnover in 2006, which was coded from 1 to 8 as indicated in Table 4 . It is expected to be positively associated with voluntary full accounts. COSTFILING (H4) captures ordinal data on the extent of agreement that the cheapest option was a major factor (see Table 4) and is expected to have a positive association with voluntary full accounts.

\subsubsection{Management factors}

ADVICE (H7) is a dummy variable $(1,0)$ that captures whether an external accountant gave advice on accounting or auditing regulations in 2006. It is expected to be positively associated with voluntary full accounts. REVIEWFILING (H8) captures nominal data on whether the directors agree they had reviewed the costs and benefits of the filing options since $2003(1,0)$. It is also expected to have a positive association with voluntary full accounts. DISCLOSETOVER (H11) captures nominal data on whether the directors agree 
disclosing turnover is or would be a major disadvantage $(1,0)$. It is expected to have a negative relationship with voluntary full accounts. $A G E(\mathrm{H} 12)$ is captures ratio data relating to the age of the company, which is calculated as 2006 (the reference year for the study) minus the year of incorporation provided by Fame. It represents the company's intrinsic advantage and is expected to have a negative relationship with voluntary full accounts. VOLAUDIT (H14) captures nominal data on whether the 2006 accounts were audited on a voluntary basis (coded 1) or the company chose exemption (coded 0 ). It is expected to be positively associated with voluntary full accounts.

\subsubsection{Agency factors}

USEFULTOUSERS (H20) captures nominal data on whether the respondents agree that their accounts filed at Companies House are useful to users $(1,0)$. It is expected to have a positive association with voluntary full accounts. INVESTORSFILING (H21), LENDERSFILING (H22), SUPPSCUSTSFILING (H23) and CREDITAGENCIES (H24) capture nominal data on whether the directors agree that potential investors/acquirers, bank/lenders, suppliers/trade creditors/customers and credit rating agencies respectively use their accounts filed at Companies House $(1,0)$. These variables are expected to be positively associated with voluntary full accounts.

\subsubsection{Control variable}

CONSISTENTFILING captures nominal data on whether the directors agree that consistency with the filing decision in previous years was a major factor $(1,0)$ and is used to control for the effect of tradition or habit.

\section{[Insert Table 4 hereabouts]}

The vast majority of registered companies (97\%) have fewer than 50 employees and $87 \%$ have fewer than 10 employees (BIS 2011, Table 3). Research shows that small firms are most vulnerable to failure during the first five years (Milne and Thomson 1986, Storey 1994). However failures or removal from the register for other reasons are offset by new incorporations. In addition, some may have crossed the size thresholds into the medium or large categories. Therefore, age is positively skewed in the population. As the other independent variables are ordinal or nominal, non-parametric tests of association and 
difference are used in the analysis. The dichotomous nature of the dependent variable makes logistic regression the appropriate choice. ${ }^{33}$ Table 5 presents descriptive statistics for the continuous variable in the analysis and Table 6 shows frequencies for the categorical variables.

\section{[Insert Tables 5 and 6 hereabouts]}

\section{Results and discussion}

\subsection{Determinants of voluntary audit}

The results of the non-parametric tests to examine differences between the two groups in VOLAUDIT and the ordinal and categorical variables are significant $(p \leq 0.01)$ for all variables apart from REVIEWAUDIT (H6). Therefore, the null hypothesis for REVIEWAUDIT cannot be rejected and this variable is excluded from the regression model. Spearman's correlation was used to check for multicollinearity among the remaining independent variables. ${ }^{34}$

Table 7 shows the results of the logistic regression of the determinants of voluntary audit for all small companies in Panel A. The following interpretation focuses on the results in Panels $\mathrm{B}$ and $\mathrm{C}$, which show the results when the small companies are separated into two groups: non-micro small companies (small companies excluding the micro-companies) and microcompanies respectively.

Looking first at the cost factors, the results for TURNOVER (H1) are highly significant in both size groups $(p \leq 0.01)$, indicating that demand for audit increases with revenue irrespective of size. COSTAUDIT $(\mathrm{H} 2)$ is also highly significant for both size groups $(p \leq$ 0.01) and the correlation coefficients carry the expected negative sign, confirming that companies choosing voluntary audit do not consider cost is a major burden. This suggests that the cost of audit is outweighed by the benefits. The benefits include both management and agency factors.

Among the management factors, the results for ADVICE (H5) are not significant for nonmicro small companies $(p>0.10)$, but are highly significant for micro-companies $(p \leq 0.01)$. 
Thus, micro-companies receiving advice on accounting and auditing regulations from their external accountant are likely to opt for voluntary audit. This extends previous research that highlights the key role played by accountants in advising on regulation in general (Blackburn et al. 2006) and on accounting and assurance in particular (Collis 2003 and Collis et al. 2004). In the context of the UK raising the turnover threshold for audit exemption from $£ 1$ million to $£ 5.6$ million in 2004, the significant results for ADVICE suggest that the audit policies pursued by very small companies in 2006 were based on informed decisions. CHECK (H9) is significant at the $10 \%$ level $(p \leq 0.10)$ for micro-companies only, giving support to the notion that audit is considered a beneficial a check on accounting systems and records in these very small companies. There is no evidence to reject the null hypotheses for QUALITY (H10) and CREDITSCORE (H13) $(p>0.10)$. The results in respect of the latter are surprising since Lennox and Pittman (2011) find evidence that small companies improve their credit ratings via the positive signal sent by continuing to have an audit when no longer legally required to do so. However, the present study measures the directors' perceptions of the effect on the company's credit rating, while Lennox and Pittman measured the actual effect. A limitation of the Lennox and Pittman study is that it focused solely on companies filing full accounts, whereas the present study investigates companies filing either full or abbreviated accounts.

An examination of the agency factors shows there is no evidence to reject the null hypotheses in respect of FAMILY (H15) ( $p>0.10)$, and although the results for EXOWNERS (H16) are significant for non-micro small companies, the correlation coefficient shows an unexpected negative sign. Therefore, the null hypothesis for H16 cannot be rejected. The results for INVESTORSAUDIT (H17) are highly significant across the size range $(p \leq 0.01)$, signifying demand for assurance from present investors, who could be minority shareholders exercising their statutory rights. LENDERSAUDIT (H18) captures directors' perceptions that the bank/lenders require audited accounts and the results are significant for micro-companies at the $10 \%$ level. Micro-companies are likely to have fewer assets and/or a shorter track record with which to demonstrate the success of the business model than non-micro small companies and audited accounts may mitigate the risk to banks providing overdrafts and other forms of debt finance in these very small companies. The correlation coefficients in respect of SUPPSCUSTSAUDIT (H19) carry an unexpected negative sign. Therefore, the perception that major customers or suppliers require audited accounts is not one of the factors 
driving the demand for voluntary audit in such companies. CONSISTENTAUDIT controls for tradition or habit and is significant for micro-companies $(p \leq 0.01)$.

The Wald statistics in Panel B of Table 7 indicate that the most powerful predictor of voluntary audit in non-micro small companies is TURNOVER (H1), followed by INVESTORSAUDIT (H17) and COSTAUDIT (H2). The pseudo $\mathrm{R}^{2}$ indicates that the model explains $78 \%$ of the variance. The Wald statistics in Panel C of Table 7 indicate that the most powerful predictor of voluntary audit in micro-companies is ADVICE (H5) followed by COSTAUDIT (H2), INVESTORSAUDIT (H17) TURNOVER (H1), LENDERSAUDIT (H18) and $C H E C K$ (H9). The pseudo $\mathrm{R}^{2}$ shows the model explains $52 \%$ of the variance. The pseudo $\mathrm{R}^{2}$ for all small companies (Panel A of Table 7) is $73 \%$. This is superior to the models of Collis (2003) and Collis et al. (2004), which only explained 39\% and 35\% of the variance respectively.

\section{[Insert Table 7 hereabouts]}

\subsection{Determinants of voluntary full accounts}

The results of non-parametric tests to examine differences between the two groups in VOLFILING and the ordinal and categorical variables were significant $(p \leq 0.05)$ for all variables. Spearman's correlation was used to check for multicollinearity among the independent variables. ${ }^{35}$

Table 8, panel A, shows the results of the logistic regression of the determinants of voluntary full accounts for all small companies. Panels B and C show the results for the non-micro small companies (small companies excluding the micro-companies) separately from the results for the micro-companies.

Starting with the cost factors, there is no evidence to reject the null hypotheses in respect TURNOVER (H3) and COSTFILING (H4). This supports previous research (Collis and Jarvis 2000, Marriott et al. 2006), which suggests the cost of preparing an additional set of abbreviated accounts solely for filing purposes is often minor due to the ease with which they can be generated by accounting software. The results for the cost factors suggest that benefits are driving the filing of voluntary full accounts. These benefits are divided into management and agency factors in the analysis. 
With regard to the management factors, there is no evidence to reject the null hypotheses in respect of ADVICE $(\mathrm{H} 7)$ and REVIEWFILING $(\mathrm{H} 8)(p>0.10)$. Therefore, receiving advice from an external accountant or reviewing the costs and benefits of their filing options since 2003 are not major predictors of voluntary full accounts. The results for DISCLOSETOVER (H11) are highly significant for the non-micro small companies $(p \leq 0.01)$ and the correlation coefficient carries the expected negative sign. This supports previous research which contends that the directors of small companies do not consider the disclosure of turnover a major disadvantage (Carsberg et al. 1985, ICAEW 1995). However, the results are not significant for micro-companies $(p>0.10)$, perhaps because their published accounts have fewer users. There is no evidence to reject the null hypothesis in respect of $A G E$ (H12) ( $p>$ 0.10), which is contrary to the findings of Dedman and Lennox (2009), but their study focused on medium-sized companies in the manufacturing sector. The results for VOLAUDIT (H14) are highly significant $(p \leq 0.01)$ for both size groups, providing evidence of a link between these two voluntary behaviours: companies choosing voluntary audit are likely to file voluntary full accounts.

Among the agency factors, the results for USEFULTOUSERS (H20) are significant for nonmicro small companies $(p \leq 0.01)$. Therefore, the directors of such companies who believe their published accounts are useful to users are likely to file voluntary full accounts. There is no evidence to reject the null hypotheses for INVESTORSFILING $(\mathrm{H} 21)(p>0.10)$. This is not surprising since most small businesses are set up to provide a living for their owners (Page 1984, Carsberg et al. 1985, Collis 2003, 2008), which makes it unlikely that the directors would file full accounts to attract potential investors/acquirers. The results for LENDERSFILING $(\mathrm{H} 22)$ are significant at the $10 \%$ level for micro-companies. This identifies the bank/lenders as the user group that the directors of micro-companies believe are using the voluntary full accounts they place on the public register. There is no evidence to reject the null hypotheses for SUPPSCUSTSFILING $(\mathrm{H} 23)$ for any of the size groups, but potential suppliers, trade creditors and major customers have the economic power to obtain detailed financial statements and do not rely on the published accounts. The correlation coefficient for CREDITAGENCIES (H24) shows an unexpected negative sign, so there is no evidence to reject the null hypothesis for H24. CONSISTENTFILING was used as a control for tradition or habit and is significant for micro-companies $(p \leq 0.10)$. 
The Wald statistics in Panel B of Table 8 indicate that the most powerful predictor of voluntary full accounts in non-micro small companies is DISCLOSETOVER (H11), followed by USEFULTOUSERS (H20) and VOLAUDIT (H14). The pseudo $\mathrm{R}^{2}$ indicates that the model explains $32 \%$ of the variance. The Wald statistics in Panel C of Table 8 indicate that the most powerful predictor of voluntary full accounts in micro-companies is VOLAUDIT (H14) followed by LENDERSFILING (H22). The pseudo $\mathrm{R}^{2}$ indicates that the model explains $24 \%$ of the variance. The pseudo $\mathrm{R}^{2}$ for all the small companies (Panel A of Table 8) is $26 \%$.

[Insert Table 8 hereabouts]

\section{Conclusions}

The motivation for this study is the lack of evidence on the link between the auditing and filing choices of small private companies in the UK. The first contribution of the study is that it increases our understanding of the drivers of voluntary audit by extending the model of Collis et al. (2004). A limitation of previous UK studies on this topic (Collis 2003, Collis et al. 2004, Collis 2010) is that they analyse predicted behaviour and focus solely on companies filing full accounts. This is addressed in the present study by focusing on the actual decisions made in the 2006 accounts (after the UK size thresholds were raised to the EU maximum in 2004) in a sample of companies filing either full or abbreviated accounts. A second contribution of the research is that it demonstrates an important link between the decision to opt for voluntary audit and the decision to file voluntary full accounts. The focus on both elements better reflects business reality, since the annual financial reporting cycle means the auditing and filing decisions coincide. A third contribution is that, to the author's knowledge, this is the first study to investigate the voluntary behaviour of micro-companies in the context of the proposed Directive on the annual accounts of micro-entities (EC 2011).

The most powerful determinant of voluntary audit in non-micro small companies is turnover. The larger the company's sales revenue, the more likely it is to have a non-mandatory audit. This is followed by perceived demand for audited accounts from investors and perceptions that the cost of audit is not a major burden. The most powerful determinant of voluntary audit in micro-companies is taking the accountant's advice, followed by perceptions that the cost of 
audit is not a major burden; perceived demand from investors; turnover; perceived demand from the bank/lenders; and the view that audit provides a check on accounting systems and records. Although there is some commonality between the two size groups, the audit decision in micro-companies is driven by a wider range of benefits that include both management and agency factors.

The most powerful determinant of voluntary full accounts in non-micro small companies is the view that disclosing turnover is not a major disadvantage, followed by the belief that the accounts they file at Companies House are useful to users and the company has a voluntary audit. The most powerful determinant of voluntary full accounts in micro-companies is that the company has a voluntary audit, followed by perceptions that the bank/lenders use their published accounts. In both size groups, there is evidence that the two voluntary behaviours are linked, but perceptions of who may be using their published accounts differ. It is notable that credit rating agencies are not seen as a significant user of the published accounts in any of the size groups studied. This may be due to an information gap or because personal credit ratings are considered to be more important in small businesses. The role of the published accounts in credit decisions requires further investigation.

Care must be taken when generalising the results of this study or comparing them with others where different selection criteria have been used. This is due to the absence of an up-to-date, complete and searchable database for private companies in the UK and problem of low response rates in empirical studies. Readers should be aware that the research was based on companies in the Fame database (excluding those in the financial intermediation sector), with a year end before 31 October 2006 (or had filed early), where the average number of employees for 2006 was given. It is not known how Fame gathered the number of employees for those filing abbreviated accounts. By discussing some of the anomalies in the UK official statistics and the challenges facing small company researchers, this paper make a further contribution to the literature that should be useful to those conducting future regulatory impact assessments.

This research demonstrates that, after the UK size thresholds were raised to the EU maxima in 2004, the benefits of placing full audited accounts on the public record outweighed the costs for a significant proportion of both non-micro small companies and micro-companies. 
The models in this study can be tested in other jurisdiction to provide further evidence to ensure that the European Commission's plans to reduce administrative burdens under the proposed Directive (EC 2011) do not have a negative impact on the intended beneficiaries. Further research is also needed to assess the potential constraint on economic growth in Europe arising from the uneven adoption of the policies, which might lead to companies in some Member States being excluded as trading partners (UEAPME 2010).

Regulation should not give the impression that there is no benefit to micro-companies from filing full audited accounts. The results of this study demonstrate non-micro small companies and micro-companies have assurance and reporting needs in common, although the specific drivers differ between the two size groups. The statutory requirement to register annual accounts ensures this important source of regulated, general purpose information is available to users, particularly those who lack the legal or economic power to demand special purpose financial statements. National regulators should take account of the information gap that would arise if micro-companies were prevented or discouraged from publishing full, audited financial information and the adverse effect this could have on the company's credit rating and, hence, its ability to borrow and obtain trade credit. 


\section{References}

Abdel-Khalik, A.R., 1993. Why Do Private Companies Demand Auditing? A case for Organizational Loss of Control. Journal of accounting, auditing \& finance, 8 (1), 31-52.

ACCA, 1998. Small Company Audits - Research study by MORI. London: Association of Chartered Certified Accountants.

Allee, K.D. and Yohn, T.L., 2009. The Demand for Financial Statements in an Unregulated Environment: An Examination of the Production and Use of Financial Statements by Privately Held Small Businesses. The accounting review, 84 (1), 1-25.

ASB, 1999. Statement of Principles for Financial Reporting. London: Accounting Standards Board.

Bennett, R. and Robson, P., 2003. External Advice and Business Links. In Cosh, A. and Hughes, A., eds. Enterprise Challenged. Cambridge: ESRC Centre for Business Research, University of Cambridge, 57-71.

Bennett, R.J. and Robson, P.J.A., 1999. The use of external advice by SMEs in Britain. Entrepreneurship and regional development, 11, 155-180.

BERR, 2007. Small and Medium-sized Enterprise (SME) Statistics for the UK and Regions 2007 [online]. Available from: http://webarchive.nationalarchives.gov.uk/20110218135832/stats.berr.gov.uk/ed/sme [Accessed 1 December 2011].

Berry, A., Citron, D. and Jarvis, R., 1987. The Information Needs of Bankers Dealing with Large and Small Companies: With particular reference to proposed changes in legislation London: Certified Accountant Publications. ACCA Research Report No. 7.

Berry, A.J., Faulkner, S., Hughes, M. and Jarvis, R., 1993. Financial Information, the Banker and the Small Business. British accounting review, 25, 131-150.

Berry, A.J., Grant, P. and Jarvis, R., 2003. Can European Banks Plug the Finance Gap for UK SMEs? London: Certified Accountants Educational Trust, ACCA Research Report No. 81.

Berry, R.H. and Waring, A., 1995. A user perspective on 'Making Corporate Reports Valuable. British accounting review, 27, 139-152.

Berry, R.H., Crum, R.E. and Waring, A., 1993. Corporate Performance Appraisal in Bank Lending Decisions. London: Chartered Institute of Management Accountants.

BIS, 2011. Business Population Estimates for the UK and Regions, 2010 [online]. Available from: http://www.bis.gov.uk/analysis/statistics/business-population-estimates [Accessed 1 December 2011].

BIS/FRC 2011. Simpler Reporting for the Smallest Businesses, Discussion Paper, August [online]. Available from: http://www.bis.gov.uk/assets/biscore/business-law/docs/s/11-1100simpler-reporting-for-smallest-businesses-discussion-paper [Accessed 1 December 2011]. 
Blackburn, R., Eadson, W., Lefebvre, R. and Gans, P., 2006. SMEs, regulation and the role of the accountant. London: Certified Accountants Educational Trust, ACCA Research Report No. 96.

Bolton, J.E., 1971. Report of the Committee of Inquiry on Small Firms, (The Bolton Report) London: HMSO, Cmnd. 4811.

Bureau van Dijk, 2011. Fame [online]. Available from: http://www.bvdinfo.com/Products/Company-Information/National/FAME.aspx [Accessed 1 December 2011].

Carsberg, B.V., Page, M.J., Sindall, A.J. and Waring, I.D., 1985. Small Company Financial Reporting. London: Prentice Hall International.

Chaney, P.K., Jeter, D.C. and Shivakumar, L., 2004. 'Self-selection of auditors and audit pricing in private firms', The accounting review, 79 (1):51-72.

Chow, C.W., 1982. The demand for external auditing: size, debt and ownership influences, The accounting review, 57 (2), 272-291.

Clatworthy, M.A. and Peel, M.J., 2007. 'The effect of corporate status on external audit fees: evidence from the UK', Journal of business finance \& accounting, 34 (1 \& 2):169-201.

Clatworthy, M.A., Makepeace, G.H. and Peel, M.J., 2009. 'Selection Bias and the Big 4 Premium: New Evidence using Heckman and Matching Models.' Accounting and business research, 39(2), 139-166.

Collis, J. and Jarvis, R., 2000. How owner-managers use accounts. London: ICAEW. Available from: http://www.icaew.com/en/technical/research-and-academics/publicationsand-projects/ /media/Files/Technical/Research-and-academics/publications-andprojects/financial-reporting-publications/how-owner-managers-use-accounts.ashx [Accessed 1 December 2011].

Collis, J. and Jarvis, R., 2002. Financial information and the management of small private companies. Small business and enterprise development, 9 (2), 100-110.

Collis, J., 2003. Directors' Views on Exemption from Statutory Audit. London: DTI, URN 03/1342. Available from: http://www.berr.gov.uk/files/file25971.pdf [Accessed 1 December 2011].

Collis, J., 2008. Directors' Views on Accounting and Auditing Requirements for SMEs [online]. Available from: http://www.berr.gov.uk/whatwedo/businesslaw/corp-govresearch/current-research-proj/page18121.html [Accessed 1 December 2011].

Collis, J., 2010. Audit exemption and the demand for voluntary audit - a comparative study of the UK and Denmark. International journal of auditing, 14 (2), 211-231.

Collis, J., Jarvis, R. and Skerratt, L., 2004. The demand for the audit in small companies in the UK. Accounting and business research, 34 (2), 87-100. 
Companies House, 2007. Statistical Tables on Companies Register Activities 2006-2007 [online]. Available from: http://www.companieshouse.gov.uk/about/pdf/companiesRegActivities2006_2007.pdf

[Accessed 1 December 2011].

Companies House, 2008. Companies Act 2006 Accounts Exemption Thresholds for companies with accounting periods starting on or after $6^{\text {th }}$ April 2008 [online]. Available from:

http://www.companieshouse.gov.uk/companiesAct/implementations/apr2008ExemptionThres hold.shtml [Accessed 1 December 2011].

Companies House, n.d. Main functions and history [online]. Available from: http://www.companieshouse.gov.uk/about/functionsHistory.shtml [Accessed 1 December 2011].

Coppens, C. and Van Wymeersch, K., 2007. An investigation into the attitude of Belgian SMEs towards the implementation of IAS/IFRS. Annual Congress of the European Accounting Association, Lisbon, April.

Cosh, A. and Hughes, A., 2003. Enterprise Challenged: Policy performance in the British SME sector 1999-2002. Cambridge: ESRC Centre for Business Research, University of Cambridge.

Cosh, A., Hughes, A., Bullock, A. and Milner, I., 2009. SME finance and innovation in the current economic crisis, Cambridge: ESRC Centre for Business Research, University of Cambridge.

Curran, J. and Blackburn, R.A., 2001. Researching the Small Enterprise. London: Sage.

Deakins, D. and Hussain, G., 1994. Financial Information, the Banker and the Small Business: A Comment. British accounting review, 26, 323-335.

Dedman, E. and Lennox, C., 2009. Perceived competition, profitability and the withholding of information about sales and the cost of sales, Journal of accounting and economics, 48 (23), 210-230.

DTI, 1995. Accounting Simplifications -A Consultative Document, London: Department of Trade and Industry, URN 95/669.

DTI, 1999. Modern Company Law for a Competitive Economy: The Strategic Framework. Company Law Steering Group. London: Department of Trade and Industry.

DTI, 2001. Modern Company Law for a Competitive Economy, Small Business Summary. Company Law Review Steering Group. London: Department of Trade and Industry, URN 01/996.

DTI, 2002. Modernising Company Law: Small Business Summary. London: Department of Trade and Industry, URN 02/1044.

DTI, 2005. Companies in 2004-2005. London: The Stationery Office, HC 544. 
DTI, 2007. Companies Act 2006: A summary of what it means for private companies. London: Department of Trade and Industry, URN 07/12.

Dyer, L. and Ross, C., 2007. Advising the small business client. International small business journal, 25 (2), 130-151.

EC, 2005. DG Internal Market Report on impacts of raised thresholds defining SMEs Impact assessment on raising the thresholds in the 4th Company Law Directive (78/660/EEC) defining small and medium sized companies, Ramboll Management, December [online]. Available from: http://ec.europa.eu/internal_market/accounting/docs/studies/sme_thresholds_en.pdf [Accessed 1 December 2011].

EC, 2007. Communication from the Commission on a simplified business environment for companies in the areas of company law, accounting and auditing, Brussels, 10 July [online]. Available from: http://ec.europa.eu/internal_market/company/simplification/index_en.htm [Accessed 1 December 2011].

EC, 2008a. 'McCreevy announces major initiatives on accounting rules for small businesses', MEMO/08/589, 29 September [online]. Available from: http://europa.eu/rapid/pressReleasesAction.do?reference=MEMO/08/589\&format=HTML\&a ged $=0 \&$ language $=E N \&$ guiLanguage $=$ en [Accessed 1 December 2011] .

EC, 2008b. Enterprises by size class - overview of SMEs in the EU. Statistics in focus 31/2008 [online]. Available from: http://ec.europa.eu/eurostat [Accessed 1 December 2011].

EC, 2011. Proposal for a Directive of the European Parliament and of the Council amending Council Directive 78/660/EEC on the annual accounts of certain types of companies as regards micro-entities. Brussels.

Eierle, B. and Haller, A., 2009. Does size influence the attitudes of preparers of financial statements towards financial accounting? The case of the ED IFRS for SMEs. Annual Congress of the European Accounting Association, Tampere, April.

Firth, M., 1979. The Impact of Size, Stock market Listing and Auditors on Voluntary Disclosure in Corporate Annual Reports. Accounting and business research, 9 (36), 273-280.

Freedman, J. and Goodwin, M., 1993. The Statutory Audit and the Micro Company - An Empirical Investigation. In Merkin, R.M., ed. The journal of business law. London: Sweet \& Maxwell, 105-130.

Gooderham, P.N., 2004. Accountants as sources of business advice for small firms. International small business journal, 22 (1), 5-22.

Haller, A. and Walton, P., 2003. Country Differences and Harmonization. In Walton, P., Haller, A. and Raffournier, B., eds. International Accounting, $2^{\text {nd }}$ ed. London: Thomson, 134.

Holgate, P., 1995. Big chance, little effort, lots of benefits. Accountancy, April, 93-94. 
Holland, J., 2005. A grounded theory of corporate disclosure. Accounting and business research, 35 (3), 249-267.

Hossain, M., Perera, M.H.B. and Rahman, A.R., 1995. Voluntary Disclosure in the Annual Reports of New Zealand Firms, Journal of international financial management \& accounting, 6 (1), 69-87.

ICAEW, 1995. Accounting Simplifications. London: Institute of Chartered Accountants in England and Wales, Technical Release FRAG 17/95.

ICAEW, 1996. Information for Members: The Needs of Small and Medium Sized Businesses. London: Institute of Chartered Accountants in England and Wales.

ICAS, 2002. Investigating the Application of the FRSSE. Edinburgh: The Institute of Chartered Accountants of Scotland.

IFAC/The Banker, 2009. SME Lender Survey [online]. Available from: http://www.ifac.org/news-events/bankerifac-survey-shows-small-business-lending-holdssteady-accountants-play-key-role-le [Accessed 1 December 2011].

IFRS, 2010. The Conceptual Framework for Financial Reporting, September, London: IFRS Foundation.

Jarvis, R., Kitching, J., Curran, J. and Lightfoot, G., 1996. The Financial Management of Small Firms: An Alternative Perspective, London: Certified Accountants Educational Trust, ACCA Research Report No. 49.

Jensen, M.C. and Meckling, W.H., 1976. Theory of the Firm: Managerial Behavior, Agency Costs and the Ownership Structure. Journal of financial economics, 3(4), 305-360.

John, B. and Healeas, S., 2000. Financial reporting standard for smaller entities: a fundamental or cosmetic change? London: Certified Accountants Educational Trust. ACCA Occasional Research Paper No. 30.

Keasey, K. and Short, H., 1990. The accounting burdens facing small firms: an empirical research note. Accounting and business research, 20 (80), 307-313.

Kervin, J.B., 1992. Methods for Business Research. New York: HarperCollins.

Kitching, J., Kašperová, E., Blackburn, R. and Collis, J., 2011. Small company abbreviated accounts: A regulatory burden or a vital disclosure? Edinburgh: Institute of Chartered Accountants in Scotland. ISBN 978-1-904574-80-4 EAN 9781904574804. Available from: http://www.icas.org.uk/site/cms/contentviewarticle.asp?article=7529 [Accessed 1 December 2011].

Leftwich, R., Watts, R.L. and Zimmerman, J.L., 1981. Voluntary corporate disclosure: the case of interim reporting. Journal of accounting research, Supplement: 50-77.

Lennox, C.S. and Pittman, J.A., 2011. Voluntary Audits versus Mandatory Audits. The accounting review, 86 (5), 1655-1678. 
Lin-Seouw, J., 2001. The Demand for the UK Small Company Audit - An Agency Perspective. International small business journal, 19 (2), 61-78.

Mages, M., 2008. Financial Reporting Practices of German Commercial Partnership in View of SME-IFRSD. Annual Congress of the European Accounting Association, Rotterdam, April.

Marriott, N., Collis, J. and Marriott, P., 2006. Qualitative review of the accounting and auditing needs of small and medium-sized companies and their stakeholders. London: Professional Oversight Board. Available from: http://www.frc.org.uk/documents/pagemanager/poba/Case\%20studies\%20report.pdf [Accessed 1 December 2011]

Meek, G.K., Roberts, C.B. and Gray, S.J., 1995. Factors Influencing Voluntary Annual Report Disclosures by US, UK and Continental European Multinational Corporations. Journal of international business studies, 26 (3), 555-572.

Milne, T. and Thomson, M., 1986. Patterns of Successful Business Start Up. In Faulkner, T. et al., eds. Readings in Small Business. London: Gower.

Morris, R. and Omrod, P., 1990. The Attitudes of Credit Analysts towards Reduced Disclosure by Small Companies. Annual Congress of the European Accounting Association, Budapest, April.

Niemi, L., Kinnunen, J., Ojala, H. and Troberg, P., 2012. Drivers of voluntary audit in Finland: To be or not to be audited? Accounting and business research, 42, doi: $10.1080 / 00014788.2012 .653742$

Olsson, R.C., 1980. The changing concept of the annual report. The chartered accountant in Australia, 51, 29-34.

Page, M.J., 1981. Auditing, Disclosure and the Small Independent Company: A Survey of Auditors, Southampton: Department of Accounting \& Management Economics Discussion Paper, University of Southampton.

Page, M.J., 1984. Corporate Financial Reporting and the Small Independent Company. Accounting and business research, 14 (55), 271-282.

POBA, 2006. Review of how accountants support the needs of small and medium-sized companies and their stakeholders. London: Professional Oversight Board for Accountancy.

Poutziouris, P., Chittenden, F. and Michaelas, N., 1998. The Financial Affairs of Private Companies. Liverpool: Tilney Fund Management.

Power, M., 1997. The Audit Society - Rituals of Verification. Oxford: Oxford University Press.

Pratten, C., 1998. The Uses of the Accounts of Small and Medium-sized Companies and the Effects of the Audit Exemption Regime. London: Institute of Chartered Accountants in England and Wales. 
Prencipe, A., 2004. Proprietary Costs and Determinants of Voluntary Segment Disclosure: Evidence from Italian Listed Companies. European accounting review, 13 (2), 319-340.

PwC, 1999. Student's Manual of Accounting, London: PricewaterhouseCoopers. ,International Thomson Business Press.

SBS, 2006. Small and Medium-sized Enterprise (SME) Statistics for the UK 2005 [online]. Available from: http://webarchive.nationalarchives.gov.uk/20110218135832/stats.berr.gov.uk/ed/sme [Accessed 1 December 2011].

Schleicher, T., 1998. Developments in Corporate Financial Disclosure over the Period 1975 1996: Evidence from UK Annual Reports. London: Association of Chartered Certified Accountants. ACCA Occasional Research Paper No. 21.

Storey, D.J., 1994. Understanding the Small Business Sector. London: Routledge.

Tauringana, V. and Clarke, S., 2000. The demand for external auditing: managerial share ownership, size, gearing and liquidity influences. Managerial auditing journal, 15 (4), 160168.

UEAPME, 2010. Parliament's OK to accounting exemptions a step back for the internal market. Brussels, Press Release 10 March. Union Européenne de l'Artisanat et des Petites et Moyennes Entreprises. Available from: http://www.ueapme.com/ [Accessed 1 December 2011].

Watson, A., Shrives, P. and Marston, C., 2002. Voluntary disclosure of accounting ratios in the UK. British accounting review, 34(2), 289-313.

Weber, M., 1968. Economy and Society. New York: Bedminster Press. 
Table 1. Financial reporting thresholds for small entities

\begin{tabular}{|lrrr|}
\hline Criteria & Proposed micro-entity & Small company & Small group \\
Turnover & $£ 0.62 \mathrm{~m}(€ 0.7 \mathrm{~m})$ & $£ 6.5 \mathrm{~m}(€ 8.8 \mathrm{~m})$ & $£ 6.5 \mathrm{~m}$ net/£7.8m gross \\
Total assets & $£ 0.31 \mathrm{~m}(€ 0.35 \mathrm{~m})$ & $£ 3.26 \mathrm{~m}(€ 4.4 \mathrm{~m})$ & $£ 3.26 \mathrm{~m} \mathrm{net} / £ 3.9 \mathrm{~m}$ gross \\
Average employees & 10 & 50 & 50 \\
\hline
\end{tabular}

Source: BIS/FRC (2011: 5), EC (2011: 4), Companies House (2008: n.p.)

Table 2. Fame search criteria and results

\begin{tabular}{|c|c|c|}
\hline Criteria & Description & Search result \\
\hline Active companies & $\begin{array}{l}\text { Active companies, those in receivership or dormant } \\
\text { (excludes companies that have been dissolved, in } \\
\text { liquidation or are otherwise inactive) }\end{array}$ & $2,622,341$ \\
\hline Registered office address & $\begin{array}{l}\text { Includes addresses in England, Scotland, Wales and } \\
\text { Northern Ireland (excludes addresses in Ireland) }\end{array}$ & $2,428,456$ \\
\hline Major sectors & $\begin{array}{l}\text { All sectors selected apart from SIC } 66 \text { Financial } \\
\text { intermediation }\end{array}$ & $1,660,746$ \\
\hline Number of employees & Minimum 0, maximum 250 in 2006 & 29,070 \\
\hline Total assets (th GBP) & Minimum 0, maximum 12,900 in 2006 & 23,678 \\
\hline Independent companies & $\begin{array}{l}\text { Excludes ultimate holding companies, companies with } \\
\text { an ultimate holding company, holding companies and } \\
\text { companies with a holding company }\end{array}$ & 14,684 \\
\hline Legal form & Private & 10,269 \\
\hline \multirow[t]{4}{*}{ Accounts type } & All & 10,238 \\
\hline & Exclusion of SIC 65 and 67 Financial intermediation & 9,998 \\
\hline & $\begin{array}{l}\text { Out of scope (no director's name, gone away, closed, in } \\
\text { liquidation, dormant, unable to participate) }\end{array}$ & $(540)$ \\
\hline & Total companies meeting criteria on 31 August 2007 & 9,458 \\
\hline
\end{tabular}


Table 3. Variables in the analysis of demand for voluntary audit

\begin{tabular}{|c|c|c|c|}
\hline $\begin{array}{l}\text { Variable } \\
\text { Cost }\end{array}$ & Definition & Hypothesis & Expected sign \\
\hline TURNOVER & $\begin{array}{l}\text { Turnover in } 2006(1=\text { up to } £ 1 \mathrm{~m}, 2=£ 1.1 \mathrm{~m}-£ 5 \mathrm{~m}, 3=£ 5.1 \mathrm{~m}- \\
£ 10 \mathrm{~m}, 4=£ 10.1 \mathrm{~m}-£ 15 \mathrm{~m}, 5=£ 15.1 \mathrm{~m}-£ 20 \mathrm{~m}, 6=£ 20.1 \mathrm{~m}-£ 25 \mathrm{~m} \text {, } \\
7=£ 25.1 \mathrm{~m}-£ 30 \mathrm{~m}, 8=\text { over } £ 30 \mathrm{~m})\end{array}$ & $\mathrm{H} 1$ & + \\
\hline COSTAUDIT & $\begin{array}{l}\text { Extent of agreement that the cost of audit was a major burden } \\
(5=\text { highest level of agreement, } 3=\text { neutral and } 1=\text { highest } \\
\text { level of disagreement })\end{array}$ & $\mathrm{H} 2$ & - \\
\hline \multicolumn{4}{|l|}{ Management factors } \\
\hline$A D V I C E$ & $\begin{array}{l}\text { Whether the company received advice on accounting or } \\
\text { auditing regulations from an external accountant in } 2006(1,0)\end{array}$ & H5 & + \\
\hline REVIEWAUDIT & $\begin{array}{l}\text { Extent of agreement that the company had reviewed the costs } \\
\text { and benefits of audit since } 2003(5=\text { highest level of } \\
\text { agreement, } 3=\text { neutral and } 1=\text { highest level of disagreement })\end{array}$ & H6 & + \\
\hline CHECK & $\begin{array}{l}\text { Extent of agreement that audit acts as a check on accounting } \\
\text { systems and records }(5=\text { highest level of agreement, } 3= \\
\text { neutral and } 1=\text { highest level of disagreement })\end{array}$ & H9 & + \\
\hline QUALITY & $\begin{array}{l}\text { Extent of agreement that audit improves the quality of the } \\
\text { financial information }(5=\text { highest level of agreement, } 3= \\
\text { neutral and } 1=\text { highest level of disagreement })\end{array}$ & H10 & + \\
\hline CREDITSCORE & $\begin{array}{l}\text { Extent of agreement that audit has a positive effect on the credit } \\
\text { rating score }(5=\text { highest level of agreement, } 3=\text { neutral and } 1 \\
=\text { highest level of disagreement) }\end{array}$ & H13 & + \\
\hline \multicolumn{4}{|l|}{ Agency factors } \\
\hline FAMILY & Whether the company is wholly family owned $(1,0)$ & H15 & - \\
\hline EXOWNERS & $\begin{array}{l}\text { Whether the company has external investors without access to } \\
\text { day-to-day financial information }(1,0)\end{array}$ & H16 & + \\
\hline INVESTORSAUDIT & $\begin{array}{l}\text { Extent of agreement that shareholders require audited accounts } \\
(5=\text { highest level of agreement, } 3=\text { neutral and } 1=\text { highest } \\
\text { level of disagreement })\end{array}$ & H17 & + \\
\hline LENDERSAUDIT & $\begin{array}{l}\text { Extent of agreement that bank/lenders require audited accounts } \\
(5=\text { highest level of agreement, } 3=\text { neutral and } 1=\text { highest } \\
\text { level of disagreement })\end{array}$ & H18 & + \\
\hline SUPPSCUSTSAUDIT & $\begin{array}{l}\text { Extent of agreement that major suppliers or major customers } \\
\text { require audited accounts }(5=\text { highest level of agreement, } 3= \\
\text { neutral and } 1=\text { highest level of disagreement) }\end{array}$ & H19 & + \\
\hline \multicolumn{4}{|l|}{ Control variable } \\
\hline CONSISTENTAUDIT & $\begin{array}{l}\text { Extent of agreement that consistency with audit decision in } \\
\text { previous years was a major factor }(5=\text { highest level of } \\
\text { agreement, } 3=\text { neutral and } 1=\text { highest level of disagreement })\end{array}$ & & \\
\hline
\end{tabular}


Table 4. Variables in the analysis of demand for voluntary full accounts

\begin{tabular}{|c|c|c|c|}
\hline Variable & Definition & Hypothesis & Expected sign \\
\hline \multicolumn{4}{|l|}{ Cost } \\
\hline TURNOVER & $\begin{array}{l}\text { Turnover in } 2006 \text { up to } £ 1 \mathrm{~m}(1), £ 1.1 \mathrm{~m}-£ 5 \mathrm{~m}(2), £ 5.1 \mathrm{~m}- \\
£ 10 \mathrm{~m}(3), £ 10.1 \mathrm{~m}-£ 15 \mathrm{~m}(4), £ 15.1 \mathrm{~m}-£ 20 \mathrm{~m}(5), £ 20.1 \mathrm{~m}- \\
£ 25 \mathrm{~m}(6), £ 25.1 \mathrm{~m}-£ 30 \mathrm{~m}(7), \text { over } £ 30 \mathrm{~m}(8)\end{array}$ & $\mathrm{H} 3$ & + \\
\hline COSTFILING & $\begin{array}{l}\text { Extent of agreement that the cheapest option was a major } \\
\text { factor }(5=\text { highest level of agreement, } 3=\text { neutral and } 1= \\
\text { highest level of disagreement })\end{array}$ & $\mathrm{H} 4$ & + \\
\hline \multicolumn{4}{|l|}{ Management factors } \\
\hline$A D V I C E$ & $\begin{array}{l}\text { Whether an external accountant gave advice on accounting or } \\
\text { auditing regulations in } 2006(1,0)\end{array}$ & $\mathrm{H} 7$ & + \\
\hline REVIEWFILING & $\begin{array}{l}\text { Whether the company had reviewed the costs and benefits of } \\
\text { the filing options since } 2003(1,0)\end{array}$ & H8 & + \\
\hline DISCLOSETOVER & $\begin{array}{l}\text { Whether disclosing turnover is/would be a major } \\
\text { disadvantage }(1,0)\end{array}$ & H11 & - \\
\hline$A G E$ & 2006 minus the year of incorporation & H12 & - \\
\hline VOLAUDIT & $\begin{array}{l}\text { Whether the } 2006 \text { accounts were audited on a voluntary basis } \\
\text { (1) or the company chose exemption (0) }\end{array}$ & H14 & + \\
\hline \multicolumn{4}{|l|}{ Agency factors } \\
\hline USEFULTOUSERS & $\begin{array}{l}\text { Whether they agree that their accounts filed at Companies } \\
\text { House are useful to users }(1,0)\end{array}$ & $\mathrm{H} 20$ & + \\
\hline INVESTORSFILING & $\begin{array}{l}\text { Whether they agree that potential investors or acquirers use } \\
\text { their accounts filed at Companies House }(1,0)\end{array}$ & $\mathrm{H} 21$ & + \\
\hline LENDERSFILING & $\begin{array}{l}\text { Whether they agree that the bank/ lenders use their accounts } \\
\text { filed at Companies House }(1,0)\end{array}$ & $\mathrm{H} 22$ & + \\
\hline SUPPSCUSTSFILING & $\begin{array}{l}\text { Whether they agree that suppliers, trade creditors or } \\
\text { customers use their accounts filed at Companies House }(1,0)\end{array}$ & $\mathrm{H} 23$ & + \\
\hline CREDITAGENCIES & $\begin{array}{l}\text { Whether they agree that credit rating agencies use their } \\
\text { accounts filed at Companies House }(1,0)\end{array}$ & $\mathrm{H} 24$ & + \\
\hline \multicolumn{4}{|l|}{ Control variable } \\
\hline CONSISTENTFILING & $\begin{array}{l}\text { Whether they agree that consistency with the filing decision } \\
\text { in previous years was a major factor }(1,0)\end{array}$ & & \\
\hline
\end{tabular}


Table 5. Descriptive statistics for continuous variable

\begin{tabular}{|lrrrrrrrrrrr|r|r|r|r|r}
\hline Variable & $N$ & Min & Max & Median & Mode & Mean & Std dev & \multicolumn{2}{c|}{ Skewness } & \multicolumn{2}{c|}{ Kurtosis } \\
& & & & & & & & Statistic & Std error & Statistic & Std error \\
AGE & 592 & 0 & 114 & 9 & 3 & 14.48 & 16.256 & 2.536 & 0.100 & 8.177 & 0.201 \\
\hline
\end{tabular}

Table 6. Frequency distributions for categorical variables

\begin{tabular}{|c|c|c|c|c|c|c|c|c|c|c|}
\hline Variable & $N$ & $\begin{array}{l}\text { Number } \\
\text { coded } 0\end{array}$ & $\begin{array}{l}\text { Number } \\
\text { coded } 1\end{array}$ & $\begin{array}{l}\text { Number } \\
\text { coded } 2\end{array}$ & $\begin{array}{l}\text { Number } \\
\text { coded } 3\end{array}$ & $\begin{array}{l}\text { Number } \\
\text { coded } 4\end{array}$ & $\begin{array}{l}\text { Number } \\
\text { coded } 5\end{array}$ & $\begin{array}{l}\text { Number } \\
\text { coded } 6\end{array}$ & $\begin{array}{l}\text { Number } \\
\text { coded } 7\end{array}$ & $\begin{array}{l}\text { Number } \\
\text { coded } 8\end{array}$ \\
\hline TURNOVER & 579 & - & 399 & 116 & 39 & 15 & 2 & 4 & 1 & 3 \\
\hline COSTAUDIT & 497 & - & 124 & 56 & 134 & 67 & 116 & - & - & - \\
\hline REVIEWAUDIT & 484 & - & 126 & 68 & 159 & 70 & 61 & - & - & - \\
\hline CHECK & 568 & - & 14 & 24 & 126 & 156 & 248 & - & - & - \\
\hline QUALITY & 555 & - & 60 & 77 & 185 & 135 & 98 & - & - & - \\
\hline CREDITSCORE & 535 & - & 61 & 51 & 202 & 137 & 84 & - & - & - \\
\hline INVESTORSAUDIT & 483 & - & 210 & 66 & 94 & 41 & 72 & - & - & - \\
\hline LENDERSAUDIT & 480 & - & 222 & 53 & 99 & 37 & 69 & - & - & - \\
\hline SUPPSCUSTSAUDIT & 474 & - & 275 & 72 & 77 & 27 & 23 & - & - & - \\
\hline CONSISTENTAUDIT & 511 & - & 109 & 43 & 123 & 108 & 128 & - & - & - \\
\hline VOLAUDIT & 592 & 362 & 230 & - & - & - & - & - & - & - \\
\hline$A D V I C E$ & 592 & 301 & 291 & - & - & - & - & - & - & - \\
\hline FAMILY & 590 & 253 & 337 & - & - & - & - & - & - & - \\
\hline EXOWNERS & 575 & 381 & 194 & - & - & - & - & - & - & - \\
\hline VOLFULL & 537 & 263 & 274 & - & - & - & - & - & - & - \\
\hline COSTFILING & 500 & 318 & 182 & - & - & - & - & - & - & - \\
\hline REVIEWFILING & 481 & 309 & 172 & - & - & - & - & - & - & - \\
\hline DISCLOSETOVER & 494 & 377 & 117 & - & - & - & - & - & - & - \\
\hline USEFULTOUSERS & 497 & 239 & 258 & - & - & - & - & - & - & - \\
\hline INVESTORSFILING & 592 & 442 & 150 & - & - & - & - & - & - & - \\
\hline LENDERSFILING & 592 & 379 & 213 & - & - & - & - & - & - & - \\
\hline SUPPSCUSTSFILING & 592 & 271 & 321 & - & - & - & - & - & - & - \\
\hline CREDITAGENCIES & 592 & 302 & 290 & - & - & - & - & - & - & - \\
\hline CONSISTENTFILING & 518 & 164 & 354 & - & - & - & - & - & - & - \\
\hline
\end{tabular}


Table 7. Demand for voluntary audit - Logistic regression

\begin{tabular}{|c|c|c|c|c|c|c|c|c|c|c|}
\hline \multirow[t]{2}{*}{ Variable } & \multirow[t]{2}{*}{$\begin{array}{l}\text { Expected } \\
\text { sign }\end{array}$} & \multicolumn{3}{|c|}{$\begin{array}{c}\text { Panel } A \\
\text { All small companies }\end{array}$} & \multicolumn{3}{|c|}{$\begin{array}{c}\text { Panel B } \\
\text { Non-micro small companies }\end{array}$} & \multicolumn{3}{|c|}{$\begin{array}{c}\text { Panel C } \\
\text { Micro-companies* }\end{array}$} \\
\hline & & $B$ & Wald & $p$ & $B$ & Wald & $p$ & $B$ & Wald & $p$ \\
\hline \multicolumn{11}{|l|}{ Cost } \\
\hline TURNOVER & + & 2.328 & 43.909 & 0.000 & 3.472 & 12.732 & 0.000 & 1.506 & 7.087 & 0.008 \\
\hline COSTAUDIT & - & -0.604 & 21.057 & 0.000 & -1.365 & 7.085 & 0.008 & -0.460 & 10.206 & 0.001 \\
\hline \multicolumn{11}{|l|}{ Management factors } \\
\hline$A D V I C E$ & + & 1.178 & 12.634 & 0.000 & 0.368 & 0.122 & 0.727 & 1.261 & 10.495 & 0.001 \\
\hline CHECK & + & 0.330 & 2.364 & 0.124 & 0.205 & 0.091 & 0.763 & 0.420 & 2.839 & 0.092 \\
\hline$Q U A L I T Y$ & + & -0.016 & 0.007 & 0.934 & 0.779 & 1.556 & 0.212 & -0.068 & 0.096 & 0.757 \\
\hline CREDITSCORE & + & -0.234 & 1.841 & 0.175 & -0.328 & 0.412 & 0.521 & -0.319 & 2.389 & 0.122 \\
\hline \multicolumn{11}{|l|}{ Agency factors } \\
\hline FAMILY & - & -0.335 & 1.004 & 0.316 & -0.622 & 0.373 & 0.541 & -0.407 & 1.057 & 0.304 \\
\hline EXOWNERS & + & -0.073 & 0.042 & 0.838 & -2.534 & 4.206 & 0.040 & -0.027 & 0.004 & 0.951 \\
\hline INVESTORSAUDIT & + & 0.700 & 20.263 & 0.000 & 2.117 & 9.391 & 0.002 & 0.530 & 8.173 & 0.004 \\
\hline LENDERSAUDIT & + & 0.283 & 2.995 & 0.084 & 0.758 & 2.650 & 0.104 & 0.403 & 3.172 & 0.075 \\
\hline SUPPSCUSTSAUDIT & + & -0.191 & 1.136 & 0.286 & -0.100 & 0.053 & 0.818 & -0.497 & 3.277 & 0.070 \\
\hline \multicolumn{11}{|l|}{ Control } \\
\hline CONSISTENTAUDIT & & 0.354 & 7.312 & 0.007 & -0.335 & 0.508 & 0.476 & 0.490 & 10.071 & 0.002 \\
\hline Constant & & -5.952 & 28.541 & 0.000 & -7.377 & 4.507 & 0.034 & -5.365 & 15.375 & 0.000 \\
\hline$N$ & & & 427 & & & 142 & & & 285 & \\
\hline Chi-square & & & 331.625 & & & 87.509 & & & 121.519 & \\
\hline-2 Log likelihood & & & 252.144 & & & 38.282 & & & 184.533 & \\
\hline Pseudo $R^{2}$ & & & 0.725 & & & 0.784 & & & 0.527 & \\
\hline
\end{tabular}

* A subset of small companies with maximum total assets of $£ 0.31 \mathrm{~m}$ and up to 10 employees 
Table 8. Demand for voluntary full accounts - Logistic regression

\begin{tabular}{|c|c|c|c|c|c|c|c|c|c|c|}
\hline \multirow[t]{2}{*}{ Variable } & \multirow[t]{2}{*}{$\begin{array}{l}\text { Expected } \\
\quad \text { sign }\end{array}$} & \multicolumn{3}{|c|}{$\begin{array}{c}\text { Panel A } \\
\text { All small companies }\end{array}$} & \multicolumn{3}{|c|}{$\begin{array}{c}\text { Panel B } \\
\text { Non-micro small companies }\end{array}$} & \multicolumn{3}{|c|}{$\begin{array}{c}\text { Panel } C \\
\text { Micro-companies* }\end{array}$} \\
\hline & & $B$ & Wald & $p$ & $B$ & Wald & $p$ & $B$ & Wald & $p$ \\
\hline \multicolumn{11}{|l|}{ Cost } \\
\hline TURNOVER & + & -0.024 & 0.031 & 0.861 & 0.006 & 0.001 & 0.977 & 0.088 & 0.167 & 0.682 \\
\hline COSTFILING & + & -0.259 & 1.003 & 0.317 & -0.198 & 0.070 & 0.791 & -0.259 & 0.850 & 0.357 \\
\hline \multicolumn{11}{|l|}{ Management factors } \\
\hline$A D V I C E$ & + & 0.046 & 0.039 & 0.843 & 0.126 & 0.064 & 0.800 & 0.069 & 0.062 & 0.804 \\
\hline REVIEWFILING & + & 0.199 & 0.654 & 0.419 & -0.339 & 0.486 & 0.486 & 0.323 & 1.148 & 0.284 \\
\hline DISCLOSETOVER & - & -0.711 & 6.764 & 0.009 & -1.438 & 6.620 & 0.010 & -0.525 & 2.652 & 0.103 \\
\hline$A G E$ & - & -0.004 & 0.381 & 0.537 & -0.009 & 0.738 & 0.390 & 0.007 & 0.410 & 0.522 \\
\hline VOLAUDIT & + & 1.091 & 13.389 & 0.000 & 1.482 & 4.384 & 0.036 & 1.192 & 10.032 & 0.002 \\
\hline \multicolumn{11}{|l|}{ Agency factors } \\
\hline USEFULTOUSERS & + & 0.604 & 6.177 & 0.013 & 1.444 & 6.241 & 0.012 & 0.466 & 2.648 & 0.104 \\
\hline INVESTORSFILING & + & -0.246 & 0.675 & 0.411 & -0.620 & 1.312 & 0.252 & -0.062 & 0.024 & 0.877 \\
\hline LENDERSFILING & + & 0.411 & 2.387 & 0.122 & 0.047 & 0.009 & 0.923 & 0.561 & 2.716 & 0.099 \\
\hline SUPPSCUSTSFILING & + & 0.308 & 1.260 & 0.262 & 1.159 & 2.549 & 0.110 & 0.130 & 0.178 & 0.673 \\
\hline CREDITAGENCIES & + & -0.008 & 0.001 & 0.975 & -1.407 & 4.067 & 0.044 & 0.272 & 0.759 & 0.384 \\
\hline \multicolumn{11}{|l|}{ Control } \\
\hline CONSISTENTFILING & & 0.606 & 6.296 & 0.012 & 0.683 & 1.905 & 0.168 & 0.573 & 3.802 & 0.051 \\
\hline Constant & & -0.955 & 8.894 & 0.003 & -0.997 & 1.062 & 0.303 & -1.304 & 10.370 & 0.001 \\
\hline $\mathrm{N}$ & & & 426 & & & 133 & & & 293 & \\
\hline Chi-square & & & 90.689 & & & 34.154 & & & 57.157 & \\
\hline-2 Log likelihood & & & 497.466 & & & 133.250 & & & 348.259 & \\
\hline Pseudo $\mathrm{R}^{2}$ & & & 0.256 & & & 0.316 & & & 0.237 & \\
\hline
\end{tabular}

* A subset of small companies with maximum total assets of $£ 0.31 \mathrm{~m}$ and up to 10 employees 
${ }^{1}$ Following restructuring of government departments in mid-2007, the Department for Business, Enterprise and
Regulatory Reform (BERR) replaced the Department of Trade and Industry (DTI). In 2009 BERR was renamed the Department for Business, Innovation and Skills (BIS).

${ }^{2}$ The Fourth Company Law Directive refers to 'abridged' accounts. The UK Companies Act 1981 used the term 'modified' accounts, which was changed to 'abbreviated' accounts in the Companies Act 1989 and remains as the term used in the Companies Act 2006.

${ }^{3}$ This category includes public corporations and nationalised bodies.

${ }^{4}$ It also specifies thresholds for eligible medium-sized entities to qualify for the abbreviated accounts that apply to them. These are not shown since the paper focuses on small and micro-entities. The thresholds are subject to periodic revision to take account of monetary and economic trends.

${ }^{5}$ After a compromise reached in the Council of Ministers in November 2011, the Legal Affairs Committee approved the thresholds for a micro-entity in the second reading the Report on the proposed Directive on the annual accounts of micro-entities. At the time of writing (January 2012), the Report still needs to be approved in a plenary session of the European Parliament.

${ }^{6}$ The provisions of the Companies Act 1981 were consolidated in the Companies Act 1985, which was amended by the Companies Act 1989 and superseded by the Companies Act 2006.

${ }^{7}$ Abbreviated accounts for medium-sized entities require a higher level of disclosure.

${ }^{8}$ Abbreviated accounts were introduced by the Companies Act 1981, which used the term 'modified accounts'. Audit exemption was introduced by a statutory instrument in 1994, which amended the Companies Act 1985.

${ }^{9}$ There were only 19 Member States at that time.

${ }^{10}$ Under the Companies Act 2006, 'an entity is excluded from the small companies regime if it is a public company, a company that is an authorised insurance company, a banking company, an e-money issuer, an ISD investment firm or a UCITS management company, or carries on insurance market activity, or is a member of an ineligible group' (c. 46, Part 15, Chapter 1, p. 178).

${ }^{11}$ These are the EU maxima from April 2008, which were adopted by the UK from the same date.

${ }^{12}$ The detailed rules are in the Companies Act 2006, c. 45, Parts 15 and 16.

${ }^{13}$ For example, content analysis based on disclosure check lists developed for multinational companies.

${ }^{14}$ By the time the consultation had been completed, the EU maxima for turnover had been raised to $£ 5.6$ million and the balance sheet total to $£ 2.8$ million. These thresholds were adopted by the UK in 2004 .

${ }^{15}$ The questionnaire for this study has now been used as the basis for government surveys in several other jurisdictions including Denmark, Finland and Sweden.

${ }^{16}$ Subsequently renamed the Professional Oversight Board (POB).

${ }^{17}$ In the USA, where financial reporting by private companies is unregulated, research shows that 'firms with audited financial statements benefit in the form of greater access to credit' (Allee and Yohn 2009, p. 1).

${ }^{18}$ Previous studies of small and/or medium-sized private companies using Fame include Collis (2003), Chaney et al. (2004), Collis et al. (2004), Clatworthy and Peel (2007), Clatworthy et al. (2009), Dedman and Lennox (2009) and Lennox and Pittman (2011).

${ }^{19}$ These represent two of the three proposed size thresholds for a medium company at the time of the survey (the 
third threshold relates to turnover).

${ }^{20}$ Section J companies were excluded because they do not qualify as 'small' or 'medium' under the Companies Act 2006.

${ }^{21}$ There may also be unknown delays in Fame adding new filings to the database.

${ }^{22}$ See Curran and Blackburn (2001, Chapter 3).

${ }^{23}$ Fame defines an active company as one that is active, in receivership or dormant. It defines an inactive company as one that has been dissolved, is in liquidation or is otherwise inactive.

${ }^{24}$ Since April 2008, this has been reduced to 9 months under the Companies Act 2006 (DTI, 2007).

${ }^{25}$ In 2007, private companies could register their accounts up to 10 months after the end of their accounting reference period.

${ }^{26}$ For example, some 448,700 private companies were incorporated in $2006-7$ and 5,880 were converted from public companies. In the same period, 224,800 were dissolved and a further 203,400 were in liquidation or in course of removal from the register (Companies House 2007, Table A2).

${ }^{27}$ This would be difficult since small companies filing abbreviated accounts do not disclose turnover and those using the small companies' regime are not required to give information about employee numbers (Companies Act 2006, c. 46, part 15, Chapter 4, p. 191).

${ }^{28}$ All turnover data exclude SIC2003 Section J (financial intermediation) where turnover is not available on a comparable basis.

${ }^{29}$ The Bolton Committee's survey asked for the completion of two questionnaires. The other questionnaire was concerned with general characteristics of the firm and achieved a $22 \%$ response rate.

${ }^{30}$ This is corroborated by the Companies House data on Fame, which shows that $63 \%$ of these companies had filed 'total exempt accounts'.

${ }^{31}$ For the purpose of this study, a micro-company is defined as a small company with a maximum balance sheet total of $£ 0.31$ million and an average of up to 10 employees during the year, representing two of the three size tests proposed for a micro-entity (see Table 1).

${ }^{32}$ Defined as a company where all shareholders had access to day-to-day internal financial information.

${ }^{33}$ The test is based on the log likelihood of the fitted model.

${ }^{34}$ The Spearman correlation matrix of the variables used to explain voluntary audit shows medium positive correlation between QUALITY and CHECK (.539), QUALITY and CREDITSCORE (.439), LENDERSAUDIT and TURNOVER (.444), INVESTORSAUDIT and LENDERSAUDIT (.661), and between INVESTORSAUDIT and SUPPSCUSTSAUDIT (.499). Correlation was low for other pairings. Since all coefficients are less than .7 $(70 \%)$, it is unlikely that there is any major overlap in their predictive power (Kervin 1992, p. 608).

35 The Spearman correlation matrix of the variables used to explain voluntary full accounts shows medium negative correlation between COSTFILING and VOLAUDIT (-.456) and low correlation for other pairings. Since all coefficients are less than $.7(70 \%)$, it is unlikely that there is any major overlap in their predictive power (Kervin 1992, p. 608). 